DOI: $10.15643 /$ libartrus-2017.1.5

\title{
The russian influence on the literary and critical writings of Mikhail Naimy
}

\author{
(C) M. L. Swanson \\ United States Naval Academy \\ 589 McNair Road, 21402 Annapolis, MD, USA.
}

Email: swanson@usna.edu

\begin{abstract}
In the article, the author studies the Russian influence on the literary, philosophical and critical works of Mikhail Naimy, the world renowned figure in modern Arabic literature. His writings contributed to changing its topics, language and style. Numerous researchers have studied the impact of British, American and French cultures and literatures on the writings of Naimy and his colleagues from the Pen Association, the literary league founded in New York by several young Arab-American emigrants. Meanwhile, it was Russian literature that had the most important impact on Naimy, especially at the earliest stages of his world formation. Scholars have only studied this influence superficially, or bring up specific Russian writers' influence, without generalization of all the Russian factors. The current work shows how Naimy incorporates Russian viewpoints on critical social reform, anticlericalism and mysticism as well as Russian literary criticism into his works. The author sums up the previous researches, generalizes all the factors, and significantly deepens the materials of the previous researches. This paper has an important methodological value, as it identifies the typology and significance of cultural contacts between the East and the West. It also contributes to an important topic that has received renewed interest from the academy-Russian influences on the Arabic world in general and on Arabic literature in particular.
\end{abstract}

Keywords: Pen Association, modern Arabic literature, Levant literature, influence of Russian literature, Mikhail Naimy, comparative literary analysis, Russian-Arabic cultural contacts, mysticism of Naimy, modern Arabic literary criticism.

The prominent Lebanese writer Mikhail Naimy (1889-1988) is the one of the canonical men of letters and founders of modern Arabic literature. His unquestionable contribution to it was in his substantial use and development of realism through his vast and diverse literary works, as well as his work in broadening its genres and in enriching its topics as well as the language in general.

In 1920 together with Jibrān Khalīl Jibrān (1883-1931), Amīn al-Rīhānī (1874-1940), Îlīyā Abū Mādī (1889(90?)-1957), and several other Arab-American men of letters, he founded a literary organization called al-RābiTah-al-Qalamiyyah (The Pen Association).

It was possible to do by incorporating into it the best achievements of foreign literatures as well as by following modern world literary currents and art directions. Naimy's merit is that he was able to synthesize not only European and American literary traditions into his native Arabic heritage. His innovative role in the founding of modern Arabic literature was in his perception and transformation of Russian literary tendencies that he organically blended into his national artistic traditions. This integration is an important part of the evolution of modern Arabic literature and an interesting phenomenon that emerged in the American melting pot of the early twentieth century.

In this article, the indispensable influence of Russian literature on Mikhail Naimy's creative writings that is understudied and unappreciated is shown, though he indicated its special place in his life and work many times. Without the precise analysis of this impact, it is hard to completely understand his multifaceted writings and the specifics of Naimy's contribution to Arabic literature. 
The Russian influence on Naimy was first noticed by the Russian scholar of Arabic language and literature Ignatii Krachkovskiī, who wrote about his first readings of Naimy, that it echoes Russian critical thought $[14$, p. 323]. He also noted the talent of the then unknown Lebanese novice writer at an early stage and included the preface that M. Naimy wrote to his 1917 play Fathers and Sons in his anthology of new Arabic literature (1928).

How did it happen that a young Lebanese alumni of schools founded by Imperial Orthodox Palestine Society of Russia (IOPSR) in Levant and the Poltavian seminary (Ukraine) was so much found and impacted by the writings of the leader of literary and social criticism of the nineteenth century and the Russian Golden and Silver age as well as by the different genres and topics of Russian literature?

This relationship started during the earlier stages of his life, when he encountered a favorable Russian cultural environment at the Russian school in his native village and in the Russian Nazareth Teacher's College. Both were founded by the Russian Imperial Orthodox Society, which followed the best pedagogical and ethical principles.

The second reason is the special time period when the young Lebanese first arrived in the distant Russia in 1905. Its Golden Age in literature was converting into the Silver one, Russian Romanticism had ceded its place to Realism several decades ago, and the last one was being replaced by Symbolism.

In addition to this, Naimy witnessed the extremely tense time between the two Russian revolutions of 1905 and 1917, when all the social contradictions sharpened to their highest degree.

One more reason for Naimy's love and admiration of Russia is related to the fact that his Poltavian period was considered by him to be the one of the happiest in his life. Life in the New World did not bring to him satisfaction. The U. S. A., which seemed to Naimy to be a melting pot of all nations and races, which was united by "the sound of a dollar, whose face is not kind" [26, vol. 2, p. 223], the preponderance of Americans' material interests over their spiritual essence, the big city lifestyle where people's lives resemble a big anthill, university students who would rather play baseball and soccer than study, were very far from his nature and deepened his loneliness [26, vol. 2, p. 222-223].

He decided to fulfill his youthful daydream "to write like the Russians" [26, vol. 1, p. 75], when he was still in Poltava. By the age of twenty-one Naimy had dramatically changed, having become a social rebel. This new turn was the result of his different life experiences, his constant spiritual strivings, the influence of the world's political and social developments, and the influence of Lev Tolstoī, among other writers, as well as the Russian revolutionaries, such as Bakunin. By the time of his graduation from the Poltavian seminary, he was thoroughly disappointed in the Arabic literature and had come to admire instead Russian and Western literature.

As was mentioned above, the American period brought luck to Naimy's creative endeavors, as it was there where he finally met his extremely talented countrymen with whom he shared his highest passion and vital concerns through working in Pen Association. The Scottish professor Hamilton Alexander Rosskeen Gibb, a scholar of Middle Eastern history and culture, has pointed out the extremely important role of al-Mahjari $\bar{l}^{1}$ literature in the development of "contemporary Arabic literature in the strict sense" [10, p. 746] in addition to the second revolutionary source, which is the new generation of Egyptian writers, literary critics and editors.

Al-Mahjari writers in their multifaceted works embraced and transformed the achievements of the European and American literatures, and synthesized them with the best Arabic literary traditions.

\footnotetext{
1 The literature created by the Levant Arab emigrants in North and South America during the late nineteenth and early twentieth centuries.
} 
Despite the fact that British and American Romanticism and Russian Critical Realism did not develop simultaneously, the Association's members were able to absorb these trends and create a new trend that blended them together with Arabic literary traditions.

The al-Mahjarī school not only helped advance modern Arabic poetry, but it also influenced other literary schools and built an information channel through which Eastern and Western literatures could exchange cultural, spiritual and moral values, as was stated by Imanquliyeva [11, p. 283]. The Pen Association raised Arabic literature to a new level through its diversification of themes and genres, and it created new forms of 1 artistic expression. These new accomplishments in the regional literature have expanded the horizons of Arabic literature and become part of the world's literary achievements. To a large extent, this was the result of the fact that many of the poets who belonged to the Pen Association wrote in English.

The phenomena of the Pen Association's literary works that blended the Western American, Russian and Arabic literary traditions is explained by the fact that its members were living far from Levant, and very often did not receive a formal education commonly practiced in its schools. At the same time, they got a chance to know world literature while staying in the Arabic diaspora. That is why their writings stayed under the impact of the Eastern and the Western literary traditions and are distinguished by a special style that significantly contributed to the development of modern Lebanese literature.

Many representatives of the Pen Association, who were educated in missionary schools in the Levant, linked themselves to Christian religious traditions. Moreh [20] notes that, since the Christian liturgical style is characterized by simplicity, deep imagination, sensitivity, lyricism, and compactness, it influenced the young poets and writers from Levant to express a tender, meditative, melancholic, and dreamy mood in a new way and create new literary and poetic forms and genres.

The Arab men of letters reflected on their former lives differently while in distant America. On the other hand, they tried not to lose a handle on their authentic selves, protecting themselves from the culture, which was still a foreign to them.

Naimy's situation was different from the overwhelming majority of his peers from the Pen Association, who drew their inspiration from American and Western European sources. Russian literature appealed to him much more than did Western European, American or even his native one, especially during the early stages of his spiritual development. Later this influence was reduced and became blended with French, American, British and Arabic influences. However, it never totally disappeared. This interesting and unusual phenomenon is explained by the fact that Naimy was living outside Lebanon during the years of his formation as a writer and he paid minimal attention to his native literature. This happened primarily because he was unfamiliar with it during this early period in his life. We can assume that neither in Biskintā's school, nor while at the Russian Nazareth College where he studied, did Naimy meet teachers who were able to spark his interest in his native literature. The passion for Arabic literature came to Naimy much later.

This also means that the main source of his influence was not an Arabic, but a Western one, and it was the Russian tradition that he really knew well.

Naimy's special role in the Pen Association follows from his background, which differed from that of his colleagues. In spite of the fact that his friends and colleagues Nasīb 'Arīdah and 'Abd al-Masīh Haddād had studied at the Russian Nazareth College, like Naimy had, and also were influenced by 
Russian literature, they did not continue their education in Russia, and they also did not have a passion for writing as the main craft of their lives at so young age, which was Naimy's case, and they certainly had not read almost all the Russian classics and modern writers in the original language.

\section{al-Nahdah}

It is also necessary to notice that Naimy's formation took place not only at the right places, but also at a time that was favorable for radical changes in literature.

At the end of the 19th century, men of letters from the most developed Arab countries gradually began deviating from traditions due to the social and the political developments in the region. It led to the emergence of the al-Nahdah (Renaissance) movement in the Arab world. It was inspired by the French Renaissance of the eighteenth century ideas and laid the groundwork for the renewal movement that started in Egypt and then spread to the Levant and Tunisia. The aim of the Arab Renaissance was to develop new Arabic philosophical, political, social and moral standards to be used in the Arab struggle against feudal ideology and cultural backwardness and to facilitate the return of the former glory and power to the Arabs. The new Arab men of letters believed in the educational mission of literature and considered mass enlightenment to be the historical need of that time as well as a reliable tool that could be used to spread new optimistic ideas of progress and the triumph of reason [6, p. 4-6]. The Arab Renaissance writers were constantly searching for new literary forms and content and taking up new tasks in literature.

\section{Reasons for Naimy's love for Russian literature}

Several reasons may account for Naimy's love of Russian literature and his preference for it over Western literature.

First of all, we should consider his unusual biography. One of the earliest and deepest influences on Naimy was The Russian School that he attended [2, p. 24]. It was founded in his native Biskintā by IOPRS as a part of its missionary campaign in the Near East [26, vol. 1, p. 76-77]. Its schools in the Middle East offered programs, textbooks and methodology superior to the better equipped [and financed] American and European missions there [15, p. 55], and the living conditions at IOPRS seminary were often better than at some students' homes.

Russian culture left an indelible mark on the rest of the seminarian graduates' lives. Students who were studying in the OIPRS schools felt deep respect towards the distant Mūscūbiyah (Russia) and were proud of living "in the shadow of the great power of Russia" [26, vol. 1, p. 78]. Starting in his youth, Naimy, like many other people in his surroundings, started to gradually warm to Russia and Russians.

Naimy continued his education at the Russian Teacher's College in Nazareth (RTCN). It was there where Naimy read his first Russian books and where he significantly expanded his knowledge of Russian language and literature, due to his "exceptional ability" [21, p. 78], persistence, and interest in world culture. By graduation, Naimy had already read some of Chekov's and Tolstoī's books, as well as Crime and Punishment by Dostoevskiī, though, as he wrote in his diaries, he did not understand half of what he read [26, vol. 1, p. 143-144].

Naimy writes in his memoirs about this time:

[Even] what little that I understood from reading Russian ...lit the flame of a passionate desire to deepen my knowledge of Russian language and literature [26, vol. 1, p. 144]... I felt like someone who is drilling a big well, but who does not have all the necessary equipment. Thus, when the story came 
to its end, I felt something similar to anger at myself, as I did not understand it all [as if I was not able] to see to the bottom of the well. There was a language barrier between me and the well that I needed to overcome. Though my Russian reading left some bitterness in my heart because of my lack of language proficiency, my admiration of Russian literature kept growing. My grief about Arabic literature compared to the Russian [was also growing]. The shameful poverty of [Arabic] literature has its roots in [our] lives. The litterateurs do not take the peel from the pit. [But] when I was really angry with our writers and poets, who were famous at that time, I also wished to be one of them... I wished I could write as these Russians write [23, p. 203].

At the same time, the young seminarian felt himself to be a creative person, and more and more he was realizing that he wanted to devote his life to creative writing.

The OPRS sent its best graduates to the Russian Empire's big cities, and Naimy was selected from several of the best students to continue his studies in Russia. At the age of 16, he arrived at the Poltava Theological Seminary (PTS) in Ukraine², where he would spend five years forming his worldview.

Naimy arrived in the distant, cold, and mysterious country of Russia at an interesting time. On the one hand, the pre-revolutionary flames of strikes and agitation were burning, but on the other hand, the early twentieth century was the blooming "Silver Age" in Russia, characterized by a large number of nascent literary currents and new ideas as well as the rejection of previous ideals, the proclamation of new aesthetics, and the emergence of a vast number of new poets and writers. Naimy not only gained knowledge of "the Golden Russian and Ukrainian Classics", but made his first attempts to analyze their literary works in his diary, which he started writing in Russian starting in 1908. Gogol's works helped him to "know better the Russian peasantry's simplicity, its patience, kindness and love of the soil" [23, p. 209].

If we sum up the first reason for Naimy's preference for Russian over his native and European literature, then we can point to the fact that before his arrival in Russia, Naimy had been already prepared to absorb its culture, as he had read the Russian Golden and Silver Age classics, and had dealt with and was impressed by the Russian educators at the Syrian schools. He was also influenced by the positive attitude Russians showed towards his motherland. These factors crated the favorable atmosphere that let Naimy continue absorbing Russian culture. This influence was reinforced by the political, social, and cultural atmosphere of pre-revolutionary Russia at the time of transition from the Golden to the Silver ages, with all the artforms, thoughts and literary diversity of those epochs.

While staying in Poltava, Naimy bitterly recorded the following in his diary:

...I could not keep myself from comparing our literature to Russian literature. What a big chasm separates us from the West! How dark is the murk in which we live! How much we are attached to life's peel that does not let us reach its pit. How poor you are, my country! Even a world torch like Tolstoī has not yet burned through the darkness of your night... [26, vol. 1, p. 233].

The paragraph cited above was not only the result of youthful maximalism of the Lebanese seminarian and his ignorance about his national literary heritage and the current situation in the Arab culture. It also probably represents some special psychological situation that needs to be studied more. That is why Naimy began his journey into the beloved world of literature by delving into Russian literature.

The relative stagnation of Arab literature (compared to Russian literature) did not discourage Naimy. On the contrary, having been inspired by the best examples of the Russian art during earlier

2 The Ukraine became the part of Russian Empire in 1654. 
stages of his life and after reading masterpieces of world literature and learning about progressive avant-garde thinking and world philosophy, Naimy was able to stand at the forefront of modern Lebanese literature and to play an important role in the creation of the modern Arabic literature.

Young Naimy, who had a passion for life in his new country that he was so found of, seemed to be interested in finding out many things about Russian culture, ranging from theater to folk songs and dances. He did not stop reading and writing about Russia and the Russians in the Russian language, straining his eyesight in the process to such an extent that he impaired his vision [26, vol. 1, p. 183]. He passionately wished to perceive Russian culture from the perspective of a Russian, and not an Arab man, and he succeeded in this.

\section{Naimy's Reading List}

In Naimy's memoirs written during his time in Poltava, we find a long, very diverse and unorganized list of Russian and Ukrainian men of letters together with his ideals and his first attempts to analyze their literary works. Much later, in 1970s, he left a relatively professional and detailed analysis of Aleksander Pushkin's, Taras Shevchenko's, Maxim Gorkiī's, Dostoevskiī's and some other Russian writers' works in his fi-l-ghirbāl al-jadìd [In the New Sieve].

Naimy used Russian and Ukrainian literature to substantiate what he already felt about this new country. If we sum up all his impressions and analysis of the Russian writers, we can notice that his entire early diary dazzles with his spontaneous comments about people belonging to different epochs and literary currents.

Naimy's reading list is long and various; it seems like he almost never missed any significant author. Among them are Nikolaī Leskov, the profound expert on Russian life and common people's souls, as well as Nikolai Gogol, whose works helped the young Lebanese writer to "know better the Russian peasantry's simplicity, its patience, kindness and love of the soil” [23, p. 209]. He argued with Leo Tolstoi in his journal about some of the concepts in War and Peace, and at the same time he learned more and more about Russia and Russians while reading about the great battles of the war against Napoleon. Fifty years later Naimy writes in his memoires:

I have found out from Tolstoī's book how the Russians shed rivers of blood while defending their Motherland, and what hellish suffering wars brought [to them]. I believed in the Russian people's desire for peace [23, p. 210].

Naimy's reading list of contemporary Russian literary works from the heydays of the Golden Age and the beginning of the Silver Age is vast.

Naimy not only passionately read the Russian novels; he was also fond of Russian poetry, especially Lermontov's romantic and psychological verses. The young seminarian says about him: "Only the Lord knows how many impressions on me this poet left" [26, vol. 1, p. 183]. He also certainly enjoyed Pushkin, the great Russian poet and the founder of modern Russian literature, together with the verses of Sergei Nikitin and Nikolai Nekrasov, who impressed Naimy not only with their rich language and beautiful narration of Russian nature, but with their sympathetic description of the common people. He admired Shevchenko's desire for freedom and love for his motherland that met his aspirations, and Semèn Nadson's decadent verses resonated with the Lebanese seminarian's youthful romanticism. At the same time, Naimy was interested in contemporary works, such as those by Chekhov, Dmitriī Merezhkovskī̄, Leonid Andreev, Alexeī Tolstoī and Alexeī Pisemskī̄.

Social life in Ukraine deeply impressed young Naimy as well. "The freedom of thought, heart, and body blinded me, and they contrasted with the disgusting stringency of my country. I felt like someone 
who is trying to scoop up the sea by the handful, or... like a hungry man who comes across a basket of figs" [26, vol. 1, p. 178]. It is no wonder that Naimy was fond of the ideas of the new pre-revolutionary Russian generation of writers, such as Gorkii [26, vol. 1, p. 173-284; 23, p. 209-211], who were glorifying a new lord, the common people [26, vol. 1, p. 230], and trying "to bring to the surface 'the lower depths' of the society and consequently [pave] the way to the socialist revolution" [23, p. 98]. Naimy, following the idea that there is no present without the past, tried to get through the major works of Nikolai Kostomarov, the Russian historian, in order to understand current events in Russia.

In addition to all of this various reading, the young seminarian seriously studied the works of Vissarion Belinskil and Vladimir Solov'év that formed the basis of literary criticism and promoted the development of philosophy in Russia [26, vol. 1, p. 173-284].

Naimy was so fully emerged into life in the Ukraine that at times he was delighted and at other times upset. Since he was trying to find an answer to all of his concerns in books, the young seminarian, naturally, turned to the Ukrainian authors in addition to the Russian ones, and specifically to the writings of Ivan Kotliarevskiī, the passionate fighter for the Enlightenment in the Ukraine and an author of the first work in the colloquial Ukrainian language.

Naimy was eager to learn the beautiful side of this new culture, like dancing and playing the violin, in which he made some progress. He was deeply impressed by visits to the Poltava Theater to see operas and ballets. The young Lebanese liked plays, and he appreciated how serious social issues were addressed on the stage. He wanted to sing Ukrainian songs, play traditional musical instruments and declaim Russian and Ukrainian poetry even better than his friends there did, and he seriously describes in his dairy his funny attempts to put on portyanki ${ }^{3}$, which were commonly worn in the Ukraine at that time [26, vol. 1, p. 177-179].

Naimy was shocked when he realized in what solitude and loneliness he had lived in his homeland where he had no one to whom he could speak about world literature, painting, music, and acting [26, vol. 1, p. 281]. He notes in his journal:

I read the writer Andreevich's An Essay in the Philosophy of Russian Literature. I was unable to do anything except to compare our literature and Russian literature. 0 Lord, what a huge chasm separates us from the West! In what darkest darkness we live! How firm is the peel with which we have covered life, so that [it does not have] its kernel. How poor are you, my country that even world stars like Tolstoì have not yet burned through your nights' darkness [26, vol. 1, p. 233].

Here we, certainly, need to take into consideration the fact that Naimy, who was so desperately writing about his native literature, just did not know it at that time. He does not mention any single Arabic literary work in his Poltava diary and at the same time compares Arabic literature in general to specific Russian authors. However, these are different categories, and that is why they are incomparable. Naimy, who undoubtedly was a real Arabic patriot, and expressed a deep and constant curiosity for Arabic history and culture, was at the same time very ignorant about his native literature. He seems to have started appreciating his native literature much later.

We also need to mention that the educational program at schools founded by ROPS included the teaching of Arabic literature and language. This distinguished it from Jesuit and Protestant schools, where the main focus was on teaching English and French languages and literatures, and Arabic language and literature were ignored [12]. It gave Naimy a significant advantage. He does not seem to take it, neither he seems to follow the advice of Nasīb 'Arīdah to read more Arabic literature during his American period, who wrote to him:

\footnotetext{
${ }^{3}$ footwraps
} 
Everything that you have written is wonderful. I just have one request for you - read more Arabic writers' works, starting with al-Yāzijī and extending to our contemporaries. Probably, you will become for us like what Belinskiī was for Russians and what Sainte-Beuve was for French people [26, vol. 2, p. 312-313].

We explain Naimy's indifference to his native literature by the fact that he just did not know it well and that neither at his village school, nor at Nazareth College, did he meet a teacher of Arabic language or literature that could inspire his interest. It seems like his Russian literature and language classes were more exciting, as he writes highly about them in his memoirs, whereas he barely mentions his Arabic ones there.

We also need to consider the fact that Naimy was very young. When he was grievously lamenting about the state of his native literature and mercilessly criticizing it, he was only between 16 and 18 years old, and in spite of his natural curiosity and observance, his judgments are, naturally, characterized by an absence of compromises, lack of life experience and knowledge, and at times by infantilism and naiveté.

Naimy penetrated life in Russia to the degree that he wanted "to become one of Russia's sons" [26, vol. 1, p. 259], sharing the feelings of its people, who were angry over the idleness of the Russian aristocracy and the poverty and oppression of its toiling workers and peasants. More and more the young seminarian felt that the church was complicit with the ruling class and how it used its authority to support the aristocracy so as not to lose its power [23, p. 212-213]. Naimy was able to find answers to his numerous questions about good and evil, social injustice and contradictive to him Orthodox religious theories in Russian literature.

This happened because of the strong influence of Eastern Christianity that laid a basis of the artistic expression of Russian literature and paid the special attention to moral and ethical issues. For many centuries Russian literature had a mostly religious and homiletic character, like the anonymous Povest' o Frole Skobeeve (Tale about Frol Skobeev).

The other foundational source of Russian literature was the Russian aristocracy of the eighteenth century (Lomonosov, Fonvizin, Derzhavin, Karamzin, among others). It was a time of struggle between different philosophical currents and foreign influences and a period when the ruling class was able to discuss its problems and ideas relatively freely without any consequences, such as political and social upheavals. Numerous debates were carried out by the aristocrats, who shunned having an official career and actively participated in these disputes. Such a situation promoted the development of a feeling of solidarity and spiritual commitment between educated Russians. The Russian aristocracy worked out its own philosophy, which was concentrated on particular issues in history, culture and life itself.

As for American and European literature, its concern for esthetics and forms has mostly prevailed over the ethical mission of literature [19]. No wonder that these tendencies did not find deep resonance in Naimy's soul in the way that Russian literature did. As Ivan Franko (1856-1916), the Ukrainian writer, wrote,

If we [merely] liked European literary works, which excited our esthetic taste and imagination, then Russian writing enraptured us, awakened our consciousness to what is human inside us, [and] awakened [our] love for the poor and aggrieved [people] [17].

Russian realism became Naimy's source of inspiration and lied the core of his worldview. His focus was changing with time, but the Russian literature and culture stayed as dominant components of Naimy's world perception till his last days. 
Naimy, both as a patriot and as a representative of the Arab intelligentsia, was tirelessly comparing his native literary works to Russian ones. The character of the Arabic literature at the end of the nineteenth century was mainly journalistic, as it was mostly touching upon socio-political topics. As for imaginative literature of that time, it still followed the old Arabic traditions in both form and content. At the same time, the changes that had begun during the Arabic Renaissance were radically converting Arabic literature into a modern one. It already had a basis in realism, though realistic situations in its plots frequently blended with fantastic ones, its conventional characters gradually began to acquire characteristics of modern personalities. New genres, such as the realistic novel and the satirical novel, appeared there along with the changes in traditional genres, such as plays where realism gradually started to prevail over Romantic and fairy tale plots.

\section{Belinskiī and Tolstoī}

Naimy was seeking for radical and positive changes in his native literature through bring to it the best achievements from other cultures. His critical works were written under the impact of Russian writers who considered enlightening of their people to be their special mission. Thus, the Lebanese writer determined the special goals for modern Arabic literture. Later Krachkovskiī highly praised Naimy's The Sieve, the collection of literary criticism articles. The Russian scholar even dared to sift through the most recognized authorities of the Arabic literature of his time [14, p. 56], so the Russian scholar clearly felt the influence of Russian literature on the young Lebanese, especially the nineteenth-century literary and theater critic Vissarion Grigor'evich Belinskiī, who earned fame for his critical articles on Russian literature [14, p. 57]. This Russian critic, who was called by his contemporaries "the vehement Vissarion", turned out to be the teacher of Russian revolutionary democrats and contributed immensely to the development of Russian literature and art's by his fiery advocacy for their new role as people's role models. He was also the one who pointed to the critical need for the new function of literature that is the reflection of life.

In addition, Belinskii's writings inspired the very observant Naimy. At the same time, numerous philosophical and social essays by Lev Nikolaevich Tolstoī (1828-1910), the philosopher and author of numerous novels and stories, attracted him no less.

Though Belinskii and Tolstoi are both notable nineteenth-century Russian writers and thinkers, they have very little in common except for their Russian origin. They led completely different lifestyles and came from different social backgrounds. Belinskiī was totally immersed in St. Petersburg's bohemian and theater life and at the same time could barely survive on the very modest income that he earned from writing. He came from a naval doctor's family with no connection to the nobility.

As for Tolstoī, he generally stayed away from the bustle of big cities and the pressures of modern society. He settled on his estate at a relatively young age, and for most of his life he enjoyed fame, glory and a very decent income. He inherited wealth and was a member of the landowning gentry. Tolstoì could trace his family's aristocratic lineage back to the thirteenth century.

What then made Naimy admire, become fascinated by and at times imitate both of these two men of letters, and why did both of them play key roles in his works?

There were several reasons for this. First and foremost, the young Lebanese writer was rapidly developing as a person and the challenges that he had to confront during his long and unusual life. The other factor that drew the Lebanese writer's attention to Belinskiī and Tolstoī was Naimy's passionate search for the truth and the fact that he could not make compromises in his fight for progress and justice. 
Naturally, he paid special attention to Tolstoī as an important figure in world philosophy. Naimy was attracted to his writings, as he was able to find in them the very same transformations that took place within himself at a young age. Naimy started his career as a priest at a very young age, but, ironically, the years spent in the seminary transformed his deep religiosity into deep and bitter disappointment in official Orthodox institutions and prompted him to look for a replacement for God. Tolstoì experienced a similar transformation, but it occurred relatively late in his life. His anarchic and at the same time pacifist philosophy and excommunication from the Russian Orthodox Church, which was broadly discussed during Naimy's stay in Russia, only made Tolstoī's personality even more interesting to the young seminarian.

We have distinguished the two main areas of this influence in the Lebanese writer's works. The first one is Belinskii and Tolstoi's shared anticlericalism. We find strong parallels in Naimy's and Tolstoì's fight against traditional clericalism and their denial of the Orthodox Church dogmas. They also rethought the human image of Jesus, and they worked out an idea of the all-mighty god as an allmighty love using similar terminology.

In his memoirs, Naimy describes in detail life in the seminary as "the embodiment of all the existing vices", such as lies, hypocrisy, theft, rumors and dissembling. At the same time, his religious world vision continued to change in Ukraine, bringing him to the sharpest crisis of his religious convictions and determining his life position. He noticed at that time, "The blanket that the church tailored for my soul became tight... and is bursting at the seams. I do not have the energy to mend it" [26, vol. 1, p. 277].

Influenced by Tolstoī's and Rousseau's ${ }^{4}$ ideas, among others, Naimy began to deny the ritual side of religion. The young Lebanese compared church services and prayers to a theater performance [26, vol. 1, p. 187] and even began to skip attending some church services.

He painfully asked himself endless questions about the Bible and Christian doctrine that he could not answer, such as the origin of evil, and what happens after death. He wondered about redemption and deliverance, and why the Lord did not correct His mistake when He saw that this world was not perfect instead of declaring a plan for judgment after death. Though Naimy still defended Christ personality and His doctrine, he found many contradictions in The Scriptures, such as plunging people into eternal fire and at the same time calling for eternal forgiveness, or calling some people damned and also calling for blessing, not damning. Naimy thought that dividing people into sinners and saints, with eternal punishment for the first group, does not agree with the Lord's love of everybody and universal justice [26, vol. 1, p. 272-281]. Naimy's sole crisis that had started in Russia brings him by the time of his graduation to the thought that the Church was so corrupt that it failed to defend people. The young Lebanese was asking himself why the Lord does not interfere in the world he created, as pains and injustice take place were everywhere [26, vol. 1, p. 224-226, 272-283].

He was also outraged by the religious despotism of the Orthodox Church that allied itself with the ruling elite [26, vol. 1, p. 257] and in the name of God crushed any liberal movement and silenced any voices that called for social justice [21, p. 63].

The second area is Naimy's and Tolstoì's social criticism and the similar position towards modern society's moral issues. Both of them were deeply upset with modern society's lifestyle and social injustice. They strongly criticized its values, especially the desire for wealth. They devoted hundreds of pages

\footnotetext{
${ }^{4}$ Jean-Jacques Rousseau was a Francophone Genevan writer and philosopher of the 18 century. He believed in "a religion of man", which is centered on morality and worship to God. He opposed this informal and unorganized belief to 'civil religion", considering it to be the formal one of a state.
} 
of their articles and literary works to attacking its ideology, which was aimed at promoting bloody wars and social repressions. They were deeply upset with the hypocrisy of those who outwardly promoted morality, but privately engaged in hidden sexual promiscuity that spread throughout modern society. Tolstoi and Naimy worked out principles of abstinence in response to this problem.

Naimy's thoughts not only about religion but also many other social and cultural phenomena developed as his familiarity with Russian literature grew. In Poltava, Naimy completely gave himself to his long-standing passion for literature, finding in it an outlet from the uneasy realities of life. Several decades later he wrote in a letter to Krachkovskiī: "While at the seminary, I quickly immersed myself in Russian literature... In front of me a truly new world was opening up that was full of wonders. I read voraciously. There was hardly a Russian writer, poet or philosopher whom I did not read exhaustively" [14, p. 225]. As a result, Naimy's eyes were constantly opened to new issues. The first thing that he came to understand was the sanctity of humanity. He felt a deep desire for perfect justice and freedom and was repulsed by the abominations of oppression and slavery [26, vol. 1, p. 230, 234, 237].

As for Belinskiin's writings, they captured the special attention of Naimy as a representative of a new Arab intelligentsia. The Lebanese man of letters did not only criticize the decline of the Arab lifestyle and literary stagnation. In his eyes, Arabic literature was not comparable to Russian and American literature, and he was looking for ways to improve it through the works of the best literary critics, asking: "Why do we not drink from the springs of our neighborhood, especially if these springs are not forbidden to us?" [24, p 126].

Naimy's contribution to the Pen Association was in extensive writing about literary criticism and literary theory. In addition to the Western European and American currents, Naimy, especially in his young age, remained strongly influenced by Russian realism, especially the critical realism.

His al-Ghirbāl [The Sieve] (1923), a collection of critical essays was called by Roger Allen, one of the leading scholars in Arabic studies, "the pioneering work of criticism published in the '20s" [14, p. 225]. Naimy not only criticized the current situation in Arabic literature, but made specific proposals for converting it into the one that would serve the needs of modern society. In The Sieve Naimy makes the distinction between what is good and what is bad in literature, and what is beautiful and ugly, as well as the robust and corrupt.

In this collection of articles the young Lebanese reflects the esthetic and critical conceptions of the Russian critic Belinskiī, who was called by Naimy "the head of Russian critics [who opened for him] the sources of truth, power, good and beauty in the literary activities and the high calling of a litterateur" [21, p. 210]. Typical characteristics of Naimy's style, such as the absence of compromises, a polemical tone, sharp criticism of stagnant literary realities, are some of the traits of Russian critical realism that Naimy was able to inject into the new Arabic literature that was just emerging.

In addition to this, Naimy's life in America sharpened one of the most distinct traits of his character: lack of any tolerance for social injustice and lies. He had seen them in his native Lebanon and in Russia. But living in America, which he did not seem to really like, deepened all his previous sufferings.

In addition to this, he could find in Belinskiî's and Tolstoì's writings the same admiration, love, respect and sympathy to the common people that was constantly growing in his heart.

\section{Language, Topics, Genres and Structure}

Naimy's knowledge of Russian and later British literature enabled him to further develop realism in Arabic literature, whose framework had already been laid by Jibrān among several other writers. Even Naimy's early stories were less sentimental and embellished, realistic, sane, and close-knit in 
comparison to what had been written before him. Moreover, he was one of the first Arab writers who was able to draw out the psychological development of his heroes [22, p. 12]. Though sentimentality was still present in his stories, especially the earliest ones, it was milder than in Jibrān's works, such as in "al-Ajnihah al-mitakassirah" ["The Broken Wings"] (1912) [22, p. 59]. Even Naimy's early sentimental literary works are not characterized by Jibrān's hopeless despair. Naimy's play Fathers and Sons deals with the same issues of arranged marriage and family violence touched on in The Broken Wings. But Naimy's literary approach differed from that of Jibrān's. The language of Fathers and Sons was not just much lighter and less bombastic than that in The Broken Wings: its plot was not overloaded with additional unnecessary characters, and its ending was not absolutely unhappy and hopeless [22, p. 59].

Russian social writings also had an important impact on Naimy. The freedom that all Arab emigrants enjoyed after leaving their motherland enabled them to finally express their suppressed deep thoughts and feelings, such as social injustice and clerical hypocrisy and corruption. In "Sanatu-ha aljadīadah" ["Her New Year"] (1914), Naimy, who also experienced a deep disappointment with the traditional church, did not only share Jibrān's critical views, but was additionally influenced by Tolstoī's criticism of official clerical institutions.

Naimy also continued to be influenced by Russian poetry. Unfortunately, all of his early verses except for "Zamerzshaia reka" ["The Frozen River"], written first in Russian and translated into Arabic during his American period, were lost [2, p. 74]. I claim that this poem represents Naimy's attempt to imitate Ivan Nikitin's (1824-1861) poetry. Naimy loved his poems, remembered them even into his old age and enjoyed reciting them [7, p. 236]. Nikitin, following Ivan Kol'tsov (1809-1842), Ivan Surikov (1841-880) and other of his literary predecessors, crafted verses that were similar to Russian folk songs. If we compare Naimy's “The Frozen River" and Nikitin's poem "Rus'” ["Russia”], for example, we notice that the young Lebanese seminarian followed the same rhyme scheme as Nikitin. Naimy recognized that his poem's rhyme was different from the traditional Arabic one. He wrote in his diary: "My [poem] was [built on] the kämil meter and maintained a rhyme only for each couplet in the European style" [26, vol. 2, p. 79-80].

In that poem, Naimy compared stagnant Russia to a frozen Sula River that would melt in the spring, which is a metaphor for the coming revolution, as, certainly, the young seminarian could not remain indifferent in the prerevolutionary atmosphere in Russia.

We can only guess that most of Naimy's other poems, like "Pokhorony liubvi" ["Funerals of Love"] [26, vol. 1, p. 185], are dedicated to the theme of love and disappointment that were popular with young people. "Funerals of Love" might have been created under the influence of early twentiethcentury decadent poetry, particularly the Russian decadent poet Nadson, who was mentioned earlier in this article. Naimy highly admired him at the time the poem was written.

The other specific feature of Russian literature that influenced Naimy was the dramatic structure of Russian literary works. Lukov [19] points out that the traditional "happy ending" of much Western literature is rarely present in Russian literature. Even when stories do end happily, its heroes in fact still suffer, as in Nikolaī Ostrovskiī's play Wrongfully Accused (1881-1883). Russian writers prefer "open endings", like in Alexander Griboyedov's play Woe from Wit (1833), Pushkin's novel in verse Eugene Onegin (1823-1831), or Gogol's novel Dead Souls (1842). Even when a story has been brought to its logical conclusion, the writer often continues his thoughts and reasoning, like in War and Peace (1863-69) by Leo Tolstoī. That is why the genre of a story with an open ending is more common in Russian literature; meanwhile, the novel with closure is more typical of Western literature. 
Naimy, who can be considered to be the one of the founders of the short story genre in Arabic literature, quite often draws direct conclusions, like Russian authors, who rarely offered direct assessments. They let their reader do it, as the message of the stories becomes clear from context [3, p. 31]. Shahīn from "Talismah" ["The Talisman"] (1919), who loses his faith in the magic power of his mascot, al-Arqash from Muzakkirāt al-Arqash [Memoires of al-Arqash] (1949), who is painfully trying to understand who he is, what his place in the Universe is, and what his motherland is, and still does not get an answer, can serve as an illustration to how Naimy concludes his works. The inner monologues of Naimy's characters that take place during the whole story, convert into their lengthy speaking for themselves in the end of the Lebanese author's writings. Naimy's heroes ask questions, but do not give readers ready answers.

Under the undoubted influence of Dostoevskii and Tolstoī, Naimy turned out to be the one of the pioneers of physiological and physical descriptions in Arabic literature. Naimy's skill in this regard is shown thorough the description of Abū Nasiff's room and his physiological state when his real thoughts mix with hallucinations in "Her New Year", the long and emotional description of Jamilah during different periods in "al-'Āqir" ["The Barren Woman"] (1914), the detailed description of 'Azīz, her husband, and al-Bīk's physical appearance from "Sa'ādat al-Bīk” [“His Excellency al-Bik”] (1919), as well as lengthy arguments about the universe, the creator and the seasons in al-Yawm al-'akhï [The Last Day] (1963). These are just a few of the examples of the kind of detailed descriptions that were very unusual for Arabic literature at that time, but which were much more typical of Russian literary writing.

The Lebanese writer devoted the main part of some of his stories to a description of the inner conflict of his heroes. He follows in the footsteps of Dostoevsky by showing sympathy towards his characters and trying to understand them and analyze their motivations and state of mind instead of offering value judgments about them. His characters' inner psyche and how Naimy connects it to the consequences of his characters' deeds truly remind us of the techniques of Russian writers. The psychological tension in his [Memoirs of al-Arqash] (1949) resembles Dostoevskiī's Prestuplenie i Narazanie [Crime and Punishment] (1866), where Niamy's al-'Arqash, like Rodion Raskol'nikov, develops from having total belief in his right to commit a crime to a deep crisis of the soul that borders on madness. Naimy touches on the same issues of freedom and necessity, good and evil, the moral responsibility that people take for their deeds and their intervention in other people's lives, God's ideas, as well as the ideas of an individual's revolt and social revolutions.

Naimy's passion for Russian literature was also reflected in his choice of a biographical genre. Naimy's Poltava and early American diaries that later took the form of an autobiographical trilogy are similar to Ivan Nikitin's The Diary of a Seminarian (1862) that Naimy read in Poltava [26, vol. 1, p. 181]. Here I would argue with Professor Nijland, who thinks that Naimy started writing his autobiography at a time when the so-called "biographie romaniceé" was flourisihing under the impact of works by Andrè Maurois, Giles Lytton Strachey, Emil Ludwig and Stefan Zweig [22, p. 67]. However, Naimy started his diary two decades earlier, in Poltava, when he remained under the strong influence of mostly Russian, rather than Western European literature.

Naimy's enthusiasm for writing and his youthful impressions of the theatre in Poltava inspired him to start writing a fundamental work in a relatively new genre ${ }^{5}$. In 1916 the young Lebanese wrote

\footnotetext{
5 We have used the term "relatively", since drama as a genre had been founded and developed in the Arab world, especially in Egypt, long ago before Naimy started to write. At the same time, note Imanquliyeva [11] considered Naimy a pioneer of the genre of Realist Arabic drama, who was influenced by Turgenev in connection with his authorship of the play discussed above.
} 
the play Fathers and Sons in three weeks [26, vol. 2, p. 342]. He borrowed the title from the famous novel by Turgenev Fathers and Sons. Naimy claimed that that title was just as trite as East and West, or Life and Death, since he described in his play the everyday topic of conflicts between generations, which was the same theme of Turgenev's novel, but his approach to the conflict between fathers and sons, their relations and plot development, was different [26, vol. 2, p. 342].

Krachkovskiī [15, p. 50] does not relate Naimy's play to Turgenev's novel. But Dolinina [6, p. 8995] claims that Naimy's position is subjective and cannot, like any author's explanation, be considered to be decisive. She did compare his play Fathers and Sons with Turgenev's novel, and she concluded that Naimy did not blindly reproduce the ideas and images of Turgenev's novel, but was inspired by them, rethought the Russian author's prototypes, and even started a polemic discussion with some of them. Though, the young Lebanese author for the first time attended theater performances in Russia, and not in Lebanon, and he was deeply affected by Russian drama.

But Naimy's main concern was in developing playwriting in Arabic literature as a genre and not engaging in trivial debates. In his preface to the first edition of Fathers and Sons, he speaks of the importance of arts in human life, since it is by watching plays and feeling empathy for the characters on the stage that people are able to experience sorrow and joy, beauty and ugliness, and distinguish between the good and the bad. It is possible to develop the national culture by inserting national leitmotifs into plays, such as songs. Naimy was searching for a solution to the question of how to use proper language for the characters in plays, given that the diglossia in the Arabic language made it difficult to develop artistic plays performed in this language. He called on others to fight against society's resistance to the recognition of plays as serious art worthy of comparison to the other genres, such as novels and poetry [24, p. 144-146].

The way Naimy saw the U. S. and the West as a whole turned Orientalism on its head and represented the writer's subconscious attempt to preserve his native culture. Moreover, quite often his view is not only that of an Arab but of a Russian as well, especially one living before the revolution, when all the contradictions inside the country and its relations with the capitalist world came into sharp relief. The way Naimy referred to himself in his American notes about the East and the West is as "Misha" (the Russian diminutive form of Mikhail) or as "a Russian in America" serve is confirmation of my hypothesis.

At the same time, Naimy did not blindly copy Russian authors. His characters live in the Arab community in the U. S. A. or in some other Arab country. Its inhabitants follow the Arab traditional lifestyle and share its values. They quite often cannot blend with the new lifestyle realities and still follow the old ones that are irrevocability gone.

Naimy's readers find in his stories numerous developments in social and political spheres that were taking place in the Middle East and the Northern Africa in the first half of the last century. This is first and foremost the result of contacts between this region with the West, which have always been riven by difference. But at the end of the nineteenth century the intensification of the cultural relations with the West led to the conflict between "the new", that was often associated with the Western culture, and "the traditional", defined by Kirpichenko and Safronov [13, p. 7] as "a complex concept that changes its content over the course of different stages of development". Though Europe was the center of world civilization, it was also the source of colonial expansion. This inevitably led to a situation where Arabic writers became more attracted to West as time passed and where local cultures influenced the literary works of the Egyptian and Levantine writers. It was a natural reaction to the globalization and the penetration of European cultures into Arabic culture. The Levantine intellectuals, 
deceived in their hopes for liberation, suffered from the new enslavement of their country. During the colonization period, more and more voices were heard about the social inequality and national oppression.

The same complicated and contradictory situation is noticed in Naimy's works. He contrasts traditional Arabic lifestyle together with its values, such as generosity, modesty and self-respect with the greedy and domineering West.

Russian experience also influenced the development of mystical elements and the combination of different religious conceptions in Naimy's literary works. Gregory Bell from Princeton University, who studies Naimy's poetry with an eye to analyzing his religious and spiritual growth. Through his analysis of the development of Romanticism's literary currents in the world, and, particularly, in Russia, Bell comes to the conclusion that Naimy's "experience in Russia was quite valuable" [2, p. 26] to his spiritual searches.

Bell claimed that Naimy first learned of theosophical ideas while in Russia, probably indirectly, before he met a Scottish member of the Theosophical Society in the U. S. [26, vol. 2, p. 341-346]. So, Naimy's first encounters with theosophy were from Russian sources, like Tolstoī's literary works ${ }^{6}$. He also became familiar with Madame Blavatskiı's writings while still in the theological seminary at that time [2, p. 97-102].

Bell thought that Naimy did not respond to theosophical ideas when he was still a young writer. His early poems were full of "social and political issues rather than the spiritual concerns that completely dominate his later works" [2, p. 191]. However, Naimy's works written during his adulthood, such as his allegorical philosophical book Kitāb al-Mirdād [The Book of Mirdad] (1948), are full of mystical elements.

Yeni Ratna Yuningsih, who studied the mystical elements of Naimy's writing, draws out the same idea. She considers the topics of the oneness of being and the transmigration of the soul as the most common themes in Naimy's mystical worldview, as well as his ideas about love and asceticism. She claims that his life in Russia had contributed considerably to his growth as a writer and a poet, as his shift to a new life style (visiting theaters, watching ballet, staying in heterosexual company) "shaped his literary art... and inspired him to write poetry, short stories and plays... [his] religious journey found its finishing touch [in Russia as well, and his life there made him reconsider] his religious model of thinking" [28, p. 23].

\section{Further Relationship with Russia}

During approximately eighty years of dialogue with Russian literature and, at times, his arguments with it, the character of Naimy's relationship, naturally, changed together with his personal

\footnotetext{
${ }^{6}$ However, Tolstoī was not a proponent of all kinds of theosophy, clairvoyance and prophesy. At the same time, Blavatsky claims in her article that Tolstoi followed theosophical ideas (1890). Moreover, she gave him her books The Voice of The Silence (1890), dedicating it as follows: "To Count Leo Tolstō, 'one of the few', from the author". Tolstoin highly valued this work, called it "Brahman Wisdom" and used quotations from it in his so-called final wisdom tracts [18]. In addition, Vladimir Nabokov, the Russian and American writer and literary critic, was the first to point out that the Buddhist idea of Nirvana is present in Tolstoi's works, such as the image of light in darkness and life in death at the end of The Death of Ivan Il'ich. The idea of reawakening through death passes through much of Tolstoī's late writings. One more example is Count Andrei Bolkonskiī's epiphany from War and Peace. Before his death, he felt the beginning of a new, eternal love. At this moment, he realizes that love is God. Since Count Bolkonskii feels himself to be a small part of global love, dying means for him a return back to this source of eternal and unconditional love. He sees his death in his dreams and feels a deep relief.
} 
and social development. It started with the author's admiration of the stunning, but not yet well understood treasure of Russian culture and his passionate desire to create a similar strong literature that would touch people's souls and address topical issues. By the end of his long and unusual life, Naimy considered Russian literature to be an important part of the classic canon, and he still considered Russian classic writers, such as Tolstoī, Gogol, Pushkin, Belinskiī, Dostoevskiī, and Gorkiī, to be the best examples of world men of letters. Starting from the end of the 1940s, Naimy's popularity outside the Arab world was rapidly growing. His works were translated into numerous languages, including English, German, Dutch, Spanish, Ukrainian, Russian, Armenian and Italian, and were published in India, Holland, Great Britain, the United States, Brazil, Italy, and several other countries. He enjoyed the special attention of the Soviet Union. In 1957, a collection of his stories was published in Moscow, and in 1958 in Ukraine, in 1974 in Azerbaijan and in 1980 the part of his memoirs devoted to Russia was translated into Russian and published.

He visited the Soviet Union several times. In 1956 the League of Soviet Writers invited him to visit Moscow, Leningrad (now St. Petersburg), Kiev, Stalingrad (now Volgograd) and Poltava. Naimy was amazed at the changes that had accrued during the fifty years he had been away. The scale of industrial development and construction, the quality of life and wellbeing of the Soviet people pleasantly shocked the Lebanese writer. Naimy gave a speech that was broadcast over Soviet radio. In it he compared life in pre- and postrevolutionary Russia, and spoke of its people with deep warmth and respect. In this speech he praised Russian culture, and first and foremost, its literature. He said in "Polveka spustia":

Thanks to [Russian classical and modern literature, I realized] ...many things that had been closed to me previously. The first [thing] that I know and understood is the sanctity of the human being. I deeply felt how beautiful justice and freedom are, and how vile are oppression and slavery [25].

Upon returning to Lebanon, he wrote his memoirs Far From Moscow and Washington, in which he describes all that he had seen while living in different countries, compares them and talks about Marxism, socialism and capitalism.

In 1962, Naimy visited the Soviet Union once again as a Lebanese delegate of the World Congress for Peace and Disarmament.

Naimy passed away in 1988. During his 99 years of life Naimy wrote 99 literary works [8]. The full collection of his writings was edited twice, in 1970 and in 1979, by the Beirut publishing house Dār al-'ilm li-al-malāin. His huge legacy is diverse; the second edition of the full collection of his works consists of nine volumes totaling over 6000 pages. It includes all of Naimy's multifaceted literary efforts: his poems, short stories, biography of Khalil Jibrān, autobiography, plays, and novels.

In 2011, a monument to Naimy was erected in Poltava, where he spent his early years. At the unveiling ceremony, Youssef Sadak, the Lebanese ambassador to Ukraine, said that Naimy today is the one of the best five writers of the Arabic world [8].

Naimy was writing at a time of global transformations in the Arabic world, including ones in its literature. The social and political changes of the first half of the twentieth century made it possible for Arab men of letters to follow numerous world literary currents. In addition to this, the unique artistic collaboration between the very young and extremely talented Arab American emigrants in the Pen Association enabled them to incorporate all kinds of literary currents and philosophical ideas that existed in the U. S. at that time into Arabic literature.

The nature of Russian literary influence on Naimy is very multifaceted, as it influenced his social views (criticism of modern civilization and anticlericalism) and introduced him to theosophy. Russian 
literature also influenced the way that the Lebanese author wrote in various literary genres (short stories, poetry, plays and other writings) and introduced him to literary theories (literary criticism), character psychological portraits and literary currents (Realism). Naimy's notable role in Arabic literary criticism was highly inspired by Belinskiī, and his social criticism and anticlericalism, which figure prominently in practically all of his works, were developed under Tolstoīs influence.

Naimy's writings remain in print and are included in the mandatory high school curriculum all over the Arabic world. His considerable contributions to modern Arabic literary criticism and modern Arabic literature make his nation proud of him.

\section{Areas for Further Research}

Our study has shown the need for deeper research into Naimy's literary works through the lens of Russian literature. Naimy's works, in turn, gave a special impulse to the development of the modern Arabic literature. So Russian literature can be said to have indirectly influenced Arabic literature through Naimy.

Because of space and research time limits, we have not touched on the distinct influence of Russian short stories, poetry and plays on how Naimy developed these genres in his native literature as well as on how the Lebanese writer developed the psychological portraits of his heroes. This opens an area for further underexplored area of research into how other Russian writers, such as Gogol, Chekhov, Nikitin, Dostoevskiī and Turgenev, influenced Naimy.

Another area that still needs to be studied better is the influence of Russian literature on American literature through the Pen Association and its contribution to a better understanding of Arabic and American modernism. Here first and foremost special attention must be paid to the development of the American realism in short stories under the influence of Russian and European literature.

In addition to this, the Russian influence on the works of the other members of the Pen Association ( Abd al-Messīḥ Ḥaddād and Nașīb `Arīḍah) who studied in Russian schools in the Levant, as Naimy did, has not been studied at all. This is one more barely studied topic for potential research.

This interesting case of literary influence can be studied as part of how modern world literature develops as part of a continual process of influences and globalization, when small national literatures become unified and in turn influence world literature. We can see the case of how one particular national literature influences another one in how Russian literature influenced the writings of a Levant writer. And he, in turn, impacted Arabic literature, which eventually became a part of world literature.

Undoubtedly, further research in the area of Russian influence on Naimy and the other members of Pen Association will uncover more interesting finds and contributions in the area of comparative literature and the development of the world literary process.

\section{References}

1. Allen R. Mīkhā’īl Nu'aymah: Promoter of the Arabic Literary Revival. C. Nijland // Journal of Near Eastern Studies. 1979. Vol. 38. No. 3. Pp. 224-226.

2. Bell G. Theosophy, Romanticism and Love in the Poetry of Mikhail Naimy. Diss. U of Pennsylvania, 2001.

3. Bilyk I. E. Tvorcheskii metod Mikhaila Nuaime. Diss. Moscow State U, 1984.

4. Blavatsky H. Leo Tolstoī and His Unecclesiastical Christianity. 1890. URL: http://www.blavatsky.net/blavatsky/arts/LeoTolstoīAndHisUnecclesiasticalChristianity.htm.

5. Dolinina A. A. Arabskī̄ perevod "Kreytserovoī sonaty L. N. Tolstogo (Kair 1904) // Arabeski. Sankt-Peterburg: Nestor-Istoriia, 2010. Pp. 290-296.

6. Dolinina A. A. Ocherki istorii arabskoī literatury novogo vremeni. Egipet I Siriia: (Publicistika 1870-1914). Moscow: Nauka. 1973. 
7. Dolinina A. A. Posleslovie // Moi semdesiat' let. Moscow: Nauka, GRVL, 1980. Pp. 222-236.

8. Dovgosheī A. V Poltave otkryli pamiatnik livantsu, kotoryī perevel na arabskī̄ shchevchenkovskī̄ "Zapovit". URL: http://news.guru.ua/news/186226/V_Poltave_otkryli_pamjatnik_livancu_kotoryj_perevel_na_arabskij_s hevchenkovskij_\%ABZapov\%B3t\%BB.html.

9. Fanous M. W. S. Aspects of the Lebanese contribution to modern Arabic literary criticism. Diss. U of Oxford, 1980.

10. Gibb H. A. R. Studies in Contemporary Arabic Literature // Bulletin of School of Oriental Studies. Vol. IV. No. 28. Pp. 745-760.

11. İmanquliyeva A. N. Korifei novoarabskoi literatury: k probleme vzaimosviazi literatur Vostoka i Zapada nachala XX veka. Baku: Elm, 1991.

12. Iuzbashan K. N. Palestinskoe obshchestvo. Stranitsy istorii // Istoricheskii Vestnik. 2000. URL: http://krotov.in fo/history/19/57/yuzb01.html.

13. Kirpichenko V. N., Safronov V. V. Istoriia egipetskoi literatury XIX-XX vekov; v dvukh tomakh. Moscow: Vostochnaiälit-ra RAN. 2002-2003.

14. Krachkovskiī I. Iu. Mikhail Nuaime // Izbrannye sochineniia. Moscow: Izd-vo Akademii nauk SSSR, 1955. Vol. 3. 223-229.

15. Krachkovskiī I. Iu. Nad arabskimi rukopisiami; listki vospominanii o knigakh i liudiakh. Izbrannye sochineniia. Moscow: Izd-vo Akademii nauk SSSR, 1955. Vol. 1. Pp. 11-139.

16. Krachkovskiī I. Iu. Vvedenie // Obraztsy novo-arabskoi literatury, 1880-1925 / Ed. Ode-Vasil'eva K. V., I. Iu. Krachkovskii. Leningrad: Izd. Leningradskogo vostochnogo instituta imeni A. S. Enukidze, 1928. I-XXV.

17. Lebedev Iu. V. Istoriia russkoī literatury v trèkh chastiakh. Part One. URL: http://www.litmir.net/br/?b=204 929.

18. Las'ko V. A. Spisok knig is Î asnopoli anskoī biblioteki. Kul'tura I vremîa \#3/4. 2004. URL: http://forum.roerich.info/showthread.php?t=12137.

19. Lukov V. A. Osnovnye osobennosti russkoi literatury. Filologiia 5. 2008. URL: http://www.zpu-journal.ru/ezpu/2008/5/Lukov_russian_literature.

20. Moreh S. Modern Arabic poetry 1800-1970: The development of its forms and themes under the influence of Western literature (Studies in Arabic literature). Brill, 1976.

21. Naimy N. N. Mikhail Naimy: An Introduction. Beirut: American U of Beirut, 1967. Oriental Series 47.

22. Nijland C. Mīkhā'îl Nu'aymah: Promoter of the Arabic Literary Revival. Istanbul: Nederlands Historisch-Archaeologisch Instituut te Istanbul, 1975.

23. Nu'aymah M. 'Ab'ad min mūskū wa wāshințūn // Mikha'il Nu'aymah. Al-majmū'ah al-kāmilah. 9 vols. Beirut: Dār al-'ālam li al-malāi'n, 1979. Vol. 6.

24. Nu'aymah M. Al-Ghirbāl // Mikha'il Nu'aymah. Al-majmū'ah al-kāmilah. 9 vols. Beirut: Dār al-'ālam li al-malāi'n, 1979.

25. Nu'aymah M. Polveka spustia. Mikhail Naimy's speech broadcasted by Soviet radio.

26. Nu'aymah M. Sab’un: hikāyat 'umr. 3 vols. Beirut: Dār Șādir, 1962.

27. Nu'aymah M. The Book of Mirdad, a Lighthouse and a Haven. Beirut: Sader's Library, 1948.

28. Yuningsih Y. R. The Mystical Element in Mikha'il Nu'aymah's Literary Works and Its Affinity to Islamic Mysticism. MA thesis. McGill U, 2001. 
DOI: 10.15643/libartrus-2017.1.5

\title{
Русское влияние на литературные и критические работы Михаила Нуайме
}

\author{
(C) М. Л. Свансон \\ United States Naval Academy \\ 589 McNair Road, 21402 Annapolis, MD, USA. \\ Email: swanson@usna.edu
}

Русская культура оказала существенное влияние на литературные, философские и критические работы всемирно известного ливанского писателя и одного из основателей современной арабской литературы Михаила Нуайме. Его труды во многом способствовали радикальному изменению традиционной арабской литературы как в развитии ее жанров и течений, так и в преобразовании ее языка. Моногочисленные исследования посвящены влияниям английской, американской и французских культур на творчество Найми и литературного сообщества молодых эмигрантов из Сирии и Ливана («Ассоциации пера»), в деятельности которого он принимал активное участие. Но в предыдущих исследованиях значение русского фактора в мировоззрении и творчестве Найми либо лишь упоминается без анализа того, в чем конкретно оно проявилось, либо в вышеуказанных работах приводятся фрагментарные примеры данного влияния без предоставления его полного спектра. Между тем, именно русское влияние было решающим в творчестве Найме, особенно на ранних этапах его становления. Данная работа обобщает предыдущие исследования и существенно дополняет и углубляет их, делая попытку представить значительно более полную картину. В статье также рассматриваются ключевые моменты влияния русской культуры на мировоззрение Нуайме и приводятся конкретные примеры данного влияния на его работы, а также на развитие его антиклерикализма и мистицизма. Статья вносит вклад в методологическое изучение типологии и значения культурных контактов Востока и Запада на конкретном примере и способствует возрождению академического интереса к вопросу русского влияния на арабский мир в целом и арабскую культуру и литературу в частности.

Ключевые слова: Ассоциация пера, современная арабская литература, сиро-ливанская литература, влияние русской литературы, Михаил Нуайме, сравнительный литературный анализ, российскоарабские культурные контакты, мистицизм Нуайме, современная арабская литературная критика.

Please, cite the article: Swanson M. L. The russian influence on the literary and critical writings of Mikhail Naimy // Liberal Arts in Russia. 2017. Vol. 6. No. 1. Pp. 48-66.

Поступила в редакцию 23.12.2016 2. После доработки - 14.02.2017 2. 